\title{
Interpretation of geographic variation in size of American eel Anguilla rostrata elvers on the Atlantic coast of North America using their life history and otolith ageing
}

\author{
Chia-Hui Wang, Wann-Nian Tzeng*
}

Department of Zoology, College of Science, National Taiwan University, No. 1, Sec. 4, Roosevelt Rd, Taipei, Taiwan 10617, ROC

\begin{abstract}
Elvers of the American eel Anguilla rostrata (LeSueur) were collected from 6 estuaries ranging in location from Haiti to the U.S. Atlantic coast and north to Canada during the fishing season in 1995. Time of metamorphosis from leptocephalus to glass eel was determined from otolith daily growth increments, in which the increment width and strontium/calcium ratios changed drastically. Mean age of the leptocephalus at metamorphosis $\left(T_{\mathrm{m}}\right)$ was 189 to $214 \mathrm{~d}$, while age upon arrival at the estuaries $\left(T_{t}\right)$ was 220 to $284 \mathrm{~d}$. Time from metamorphosis to arrival at the estuaries $\left(T_{1-m}\right)$ was 32 to $80 \mathrm{~d}$ Faster-growing and earlier-metamorphosing leptocephali migrate to the mid-point of the sampling range, but slower-growing and delayed-metamorphosis leptocephali occur in both the southern and northern ranges. Duration of the glass eel phase was longer in the north than in the south, while glass eels grew faster in the south than in the north. Mean total length of elvers at entry to the estuaries increased significantly from $48 \mathrm{~mm}$ in the south to $60 \mathrm{~mm}$ in the north. Geographic variation in elver length was due to duration of the glass eel phase rather than timing of metamorphosis from leptocephalus to glass eel, because elver length was significantly positively correlated with $T_{t-m}(r=0.79$, $p<0.01)$ but not significantly correlated with $T_{m}(p>0.05)$. Duration of the glass eel phase was influenced by the coastal oceanographic conditions.
\end{abstract}

KEY WORDS: Otolith microchemistry Aging - Early life history - Geographic variation in size - Elvers American eel

\section{INTRODUCTION}

The American eel Anguilla rostrata (LeSueur) is a temperate catadromous fish, widely distributed in the rivers of eastern North and Central America (Schmidt 1909). Developmental stages of the American eel are similar to those of Anguilla anguilla and include: leptocephalus, glass eel, elver, yellow eel and silver eel (Bertin 1956). The American eel has a panmictic population (Avise et al. 1986) which spawns in the Sargasso Sea in the southwestern North Atlantic Ocean (Schmidt 1925, Kleckner et al. 1983, Kleckner \& McCleave

\footnotetext{
- Addressee for correspondence
}

E-mail:wnt@ccms.ntu.edu.tw
1988). After a long-distance oceanic migration, the leptocephali metamorphose to glass eels on the continental shelf, and then become elvers in the estuaries (Bertin 1956, Tesch 1977). Due to their wide distribution in the open ocean and difficulty in collection, the biology of leptocephali is poorly known (Kleckner \& McCleave 1982, 1985, Schoth \& Tesch 1982, Castonguay \& McCleave 1987, Miller \& McCleave 1994j. The size of elvers at entry to the estuary tends to increase with increasing distance from the spawning area (Vladykov 1966, Smith 1968, Haro \& Krueger 1988). This phenomenon was initially explained by a sex/size hypothesis that the female grows faster than the male and that the female predominates more in the north than in the south (Vladykov 1966). Haro \& Krueger 
(1988) rejected Vladykov's hypotheses and proposed that the geographic trend in elver length may be due to the variation in the timing of metamorphosis of leptocephali to the glass eel stage. However, until now there have been no studies on the age determination of leptocephalus at metamorphosis to substantiate this speculation.

Daily growth increments in otoliths (Pannella 1971) have been widely used to determine the daily age (Campana \& Neilson 1985), growth rate (Volk et al. 1984), life history and change of habit of fish (Campana 1984). The age of Japanese eel Anguilla japonica elvers at metamorphosis and entry to various estuaries has been extensively studied (Tsukamoto \& Umezawa 1990, 1994, Tzeng 1990, 1996 , Otake et al. 1994, Tzeng \& Tsai 1994,

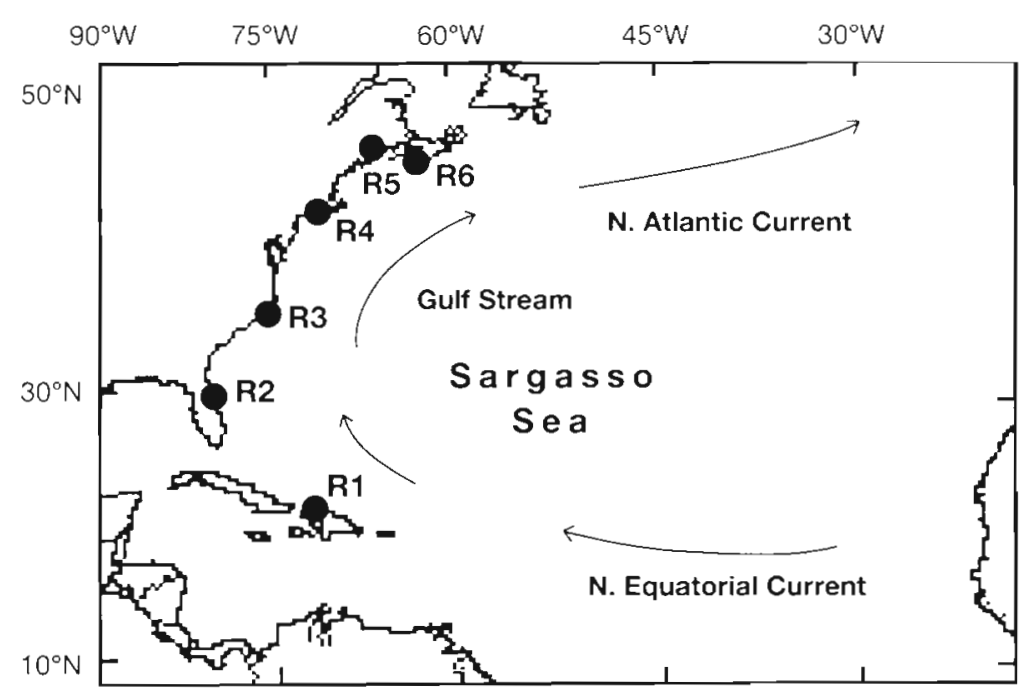

Fig. 1 Sampling sites of Anguilla rostrata elvers (R1. Haiti; R2: Florida; R3 North Carolina; R4: Rhode Island; R5: New Brunswick; R6: Nova Scotıa)

Cheng \& Tzeng 1996). These studies con-

clude that a visible metamorphosis check is deposited in the otolith at metamorphosis. Strontium concentration in the otolith decreases dramatically during metamorphosis. Since growth increments in otoliths of American eel elvers are deposited daily (Martin 1995), the age of the leptocephalus at metamorphosis and the age of the elver at entry to the estuary can be determined from daily growth increments and the strontium content of the otolith.

This study investigates the causes of the geographic variation in size of American eel elvers on the east coasts of North America and Haiti by using the microstructure and microchemistry of otoliths.

\section{MATERIALS AND METHODS}

American eel elvers were collected from 6 estuaries on the Atlantic coasts of Haiti, the USA and Canada (Table 1, Fig. 1). All samples were collected in 1995, with 1 additional sample collected in 1997 from Florida because the corresponding sample size in 1995 was small. The elvers were collected with a dip net during their upstream migration on a night-time flood tide (Usui 1991) and were preserved in $95 \%$ alcohol. Total lengths to $0.1 \mathrm{~mm}$ were measured after alcohol fixation. Pigmentation stages, which indicate the developmental stage from glass eel to elver, were assessed according to pigment distribution on the body surface (Strubberg 1913). Sagittal otoliths of the elvers were extracted from the vestibular apparatus and prepared for microchemistry analysis and age determination as described by Tzeng $(1990,1996)$ and Tzeng \& Tsai (1994).
EPMA (Electron Probe Microanalysis; EPMA Model 8800 ) was used to analyze the weight ratio ( $w$ t \%o) of strontium (Sr) to calcium (Ca) in eel otoliths. $\mathrm{SrTiO}_{3}$ and $\mathrm{CaCO}_{3}$ were used as standards for $\mathrm{Sr}$ and $\mathrm{Ca}$, respectively. Sr and $\mathrm{Ca}$ were measured along the otolith maximum axis through the primordium with a beam condition of $0.01 \mu \mathrm{A}$ and $15 \mathrm{kV}$. At intervals of approximately $10 \mu \mathrm{m}$, the electron beam was focused on an area approximately $5 \mu \mathrm{m}$ in diameter. The energy dispersive strength of Ca and $\mathrm{Sr}$ was evaluated using four 5 s scanning periods. After $Z$ AF $(Z$, atomic number effect; $A$, absorption factor; $F$, fluorescence effects) correction (Goldstein et al. 1984), the weight ratio of $\mathrm{Sr}$ and $\mathrm{Ca}$ was calculated using a constant $\mathrm{CO}_{2}$ of $43.87 \%$ (Chen \& Tung 1984). The metamorphosis check at which the leptocephalus metamorphosed to the glass eel stage was inferred from the point at which the Sr/Ca ratio changed (Tzeng \& Tsai 1994, Tzeng 1996). To link the time series change of Sr/Ca ratio with otolith growth increment, the otolith was washed

Table 1. Sampling sites (shown in Fig. 1) and dates and sample sizes of Anguilla rostrata elvers

\begin{tabular}{|lllr|}
\hline Site & & Date & N \\
\hline R1 & Haiti & Dec 17, 1995 & 115 \\
R2 & Florida, USA & Feb 28, 1995 & 4 \\
R3 & North Carolina, U.S.A. & Man 22, 1997 & 50 \\
R4 & Annaquatucket River, & Apr 1995 & 50 \\
R5 & Rhode lsland, USA & Apr, 1995 & 100 \\
Rusquash River, & New Brunswick, Canada & Apr 28, 1995 & 67 \\
R6 & East River, Nova Scotia, Canada & May 29, 1995 & 93 \\
\hline
\end{tabular}




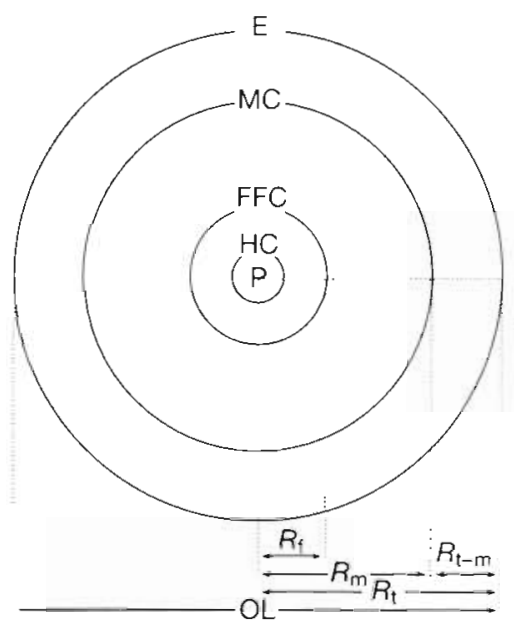

Fig. 2. A schematic diagram of radii measurements in elver otoliths. P: primordium; HC: hatching check; FFC: first feeding check; MC: metamorphosis check; E: edge. Radii were measured from the primordium to the first feeding check $\left(R_{f}\right)$. to the first feeding check $\left(R_{\mathrm{m}}\right)$ metamorphosis check, and to the otolith edge $\left(R_{1}\right) ; R_{1-m}$ : distance from the metamorphosis check to the otolith edge; OL: otolith length

with acetone to take off the carbon coating after EPMA analysis and was then prepared for age determination using an SEM (scanning electron microscope, Hitachi S-520) (Tzeng 1996).

Otolith radii from the primordium to the first feeding check $\left(R_{\mathrm{f}}\right)$, to the metamorphosis check $\left(R_{\mathrm{m}}\right)$ and to the otolith edge $\left(R_{1}\right)$ and the distance from the metamorphosis check to the otolith edge $\left(R_{t-m}\right)$ were measured using an SEM photograph taken at $300 \times$ magnification along the longest sagittal axis of the otolith (Fig. 2). The growth increments $\left(N_{m}, N_{t-m}\right.$, and $\left.N_{t}\right)$ on the radij of $R_{\mathrm{m}}, R_{\mathrm{t}-\mathrm{m}}$, and $R_{\mathrm{t}}$ were counted on SEM photographs at $1200 \times$ magnification. Because increments are not deposited in the core of the otolith for the $5 \mathrm{~d}$ of the yolk-sac stage (Yamamoto \& Yamauchi 1974, Yamauchi et al. 1976. Tzeng 1990, Tzeng \& Tsai 1994), 5 d $\left(N_{0}\right)$ were added to the number of growth increments to estimate the daily age of elvers at metamorphosis $\left(T_{\mathrm{m}}=N_{\mathrm{m}}+N_{0}\right)$ and the daily age at estuarine arrival $\left(T_{1}=N_{1}+N_{0}\right)$. The time between metamorphosis and arrival at the estuary $\left(T_{t-m}\right)$ equals $N_{1-m}$. Daily growth increments were counted for 89 otoliths.

Three kinds of otolith growth rate estimates were made:

Overall growth rate of otolith, $G_{\mathrm{t}}=R_{\mathrm{t}} / T_{\mathrm{l}}$

Early growth rate of otolith, $G_{\mathrm{m}}=R_{\mathrm{m}} / T_{\mathrm{m}}$

Estuarine growth rate of otolith, $G_{\mathrm{l}-\mathrm{m}}=R_{\mathrm{l}-\mathrm{m}} / T_{1-\mathrm{m}}$ (3)

Because the counting of daily growth increments was time consuming and the increments near the metamorphosis area on the otolith were often diffusive and obscure, the daily age of samples without counting daily growth increment was calculated from otolith growth rate and otolith radius

$$
\begin{aligned}
& T_{\mathrm{m}}=\frac{R_{\mathrm{m}}-R_{\mathrm{f}}}{G_{\mathrm{m}}}+N_{0} \\
& T_{\mathrm{t}-\mathrm{m}}=\frac{R_{\mathrm{l}-\mathrm{m}}}{G_{\mathrm{t}-\mathrm{m}}} \\
& T_{\mathrm{t}}=T_{\mathrm{m}}+T_{\mathrm{l}-\mathrm{m}}
\end{aligned}
$$

where $G_{m}$ and $G_{1-m}$ were obtained from Eqs. (2) \& (3), and $N_{0}$ is the adjustment factor $(5 \mathrm{~d})$ for yolk-sac stage duration. Otolith growth rate of the elvers in the 6 estuaries was site-specific i $_{i}$ the rate was calculated at each sampling site to estimate daily ages.

The homogeneity of mean total length, various daily ages $\left(T_{t}, T_{m}\right.$, and $\left.T_{1-m}\right)$ and otolith growth rates $\left(G_{t}\right.$, $G_{m}$, and $G_{t-m}$ ) among the 6 estuaries was tested with Scheffe's multiple range analysis (Sokal \& Rohlf 1969). Correlations between total length and $T_{\mathrm{t}}, T_{\mathrm{m}}$ and $T_{\mathrm{t}-\mathrm{m}}$ for the elvers were calculated.

\section{RESULTS}

\section{Total length and pigment stage}

Total lengths of the elvers collected from the 6 estuaries on the Atlantic coasts of Haiti and North America ranged between 41 and $65 \mathrm{~mm}$. Two different length groups were identified: mean length of the northern group [Nova Scotia (R6), New Brunswick (R5) and Rhode Island (R4)] was significantly greater than that of the southern group (North Carolina (R3), Florida (R2) and Haiti (R1)]. Mean lengths ranged from 47.8 to $49.0 \mathrm{~mm}$ for the southern group and from 58.5 to $60.0 \mathrm{~mm}$ for the northern group, with a difference in mean length of approximately $12 \mathrm{~mm}$ (Fig. 3).

The pigment development stage of elvers at estuarine arrival was mostly VB and VIA1 for R2, but VIA1 and VIA2 for the other 5 sites. This may indicate that the immigration of elvers in Florida occurred at an earlier stage than for the other sites. In addition, the trend of mean total length of elvers from different sampling sites was similar among pigmentation stages, indicating that the difference in mean length between northern and southern groups was independent of elver pigmentation stage (Fig. 4)

\section{Otolith microstructure and microchemistry}

The primordium of the elver otoliths was amorphous. Between the hatching check ( $\mathrm{HC}$ ) and the first feeding 

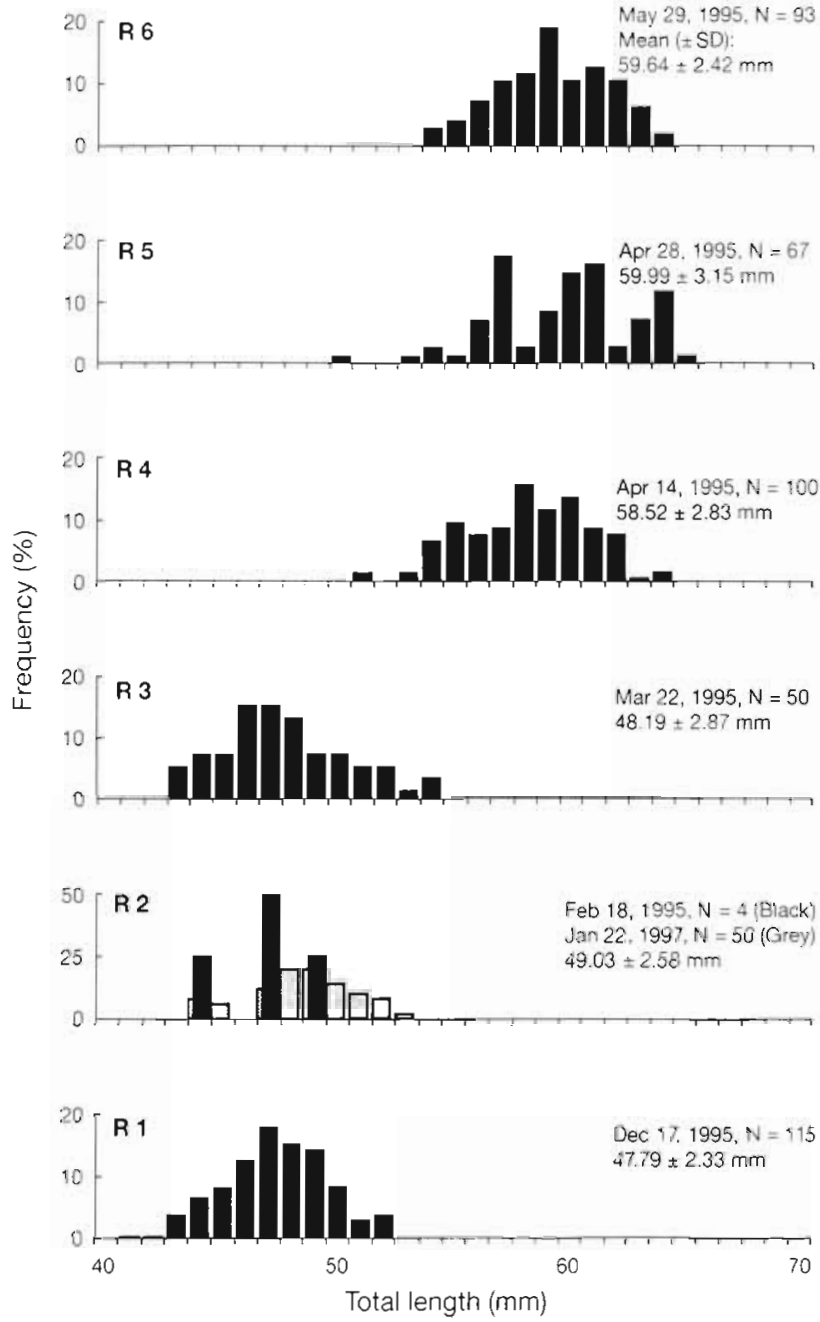

Fig. 3. Anguilla rostrata. Length frequency distribution of elvers collected from 6 estuaries in Haiti and North America (Sites R1 to R6 in Fig. 1). Mean $\pm \mathrm{SD}$ of each distribution is also indicated

check ( $F F C$ ), no distinct daily growth was discernible. Beyond the FFC, there were distinct daily growth increments. The shape of the otolith crystalline arrangement changed from a circular to a radial form at approximately $2 / 3$ of the total radius distance from the primordium. Also, the increment widths at the transition boundary become very narrow. The changes in both crystalline pattern and increment width yielded a distinct check, which was interpreted as the metamorphosis check (MC) (Fig. 5).

Changes in crystalline arrangement and increment width in the otolith reflect different developmental stages of the fish. The nucleus from the primordium to the FFC, which is deposited before the yolk-sac stage, has no discernible daily growth increments. The mean nucleus radius ranged between 9.5 and $15.0 \mu \mathrm{m}$. The zone from the FFC to the MC was deposited during the leptocephalus stage. Daily growth increments were wide and clear in the beginning of the stage, but became indistinct and almost uncountable across the MC check. This indicated that the growth of the leptocephalus was fast in the early stage and then gradually slow. From the MC to the otolith edge, the crystalline arrangement became radial in form and had wide increments, indicating that growth became fast after metamorphosis (Fig. 5). Daily growth increments from the $\mathrm{MC}$ to the otolith edge were wider in the southern grap than in the northern group of elvers, i.e. the daily growth of glass eel in the period after metamorphosis was faster in the southern group than in the northern group.

$\mathrm{Sr} / \mathrm{Ca}$ ratio in otoliths was approximately $5 \times 10^{-3}$ in the nucleus and increased with otolith growth, reaching a maximum ranging between 1.4 and $2.0 \times 10^{-2}$ at the $\mathrm{MC}$. Beyond the check, the $\mathrm{Sr} / \mathrm{Ca}$ ratio sharply decreased (Fig. 6). The dramatic changes in $\mathrm{Sr} / \mathrm{Ca}$
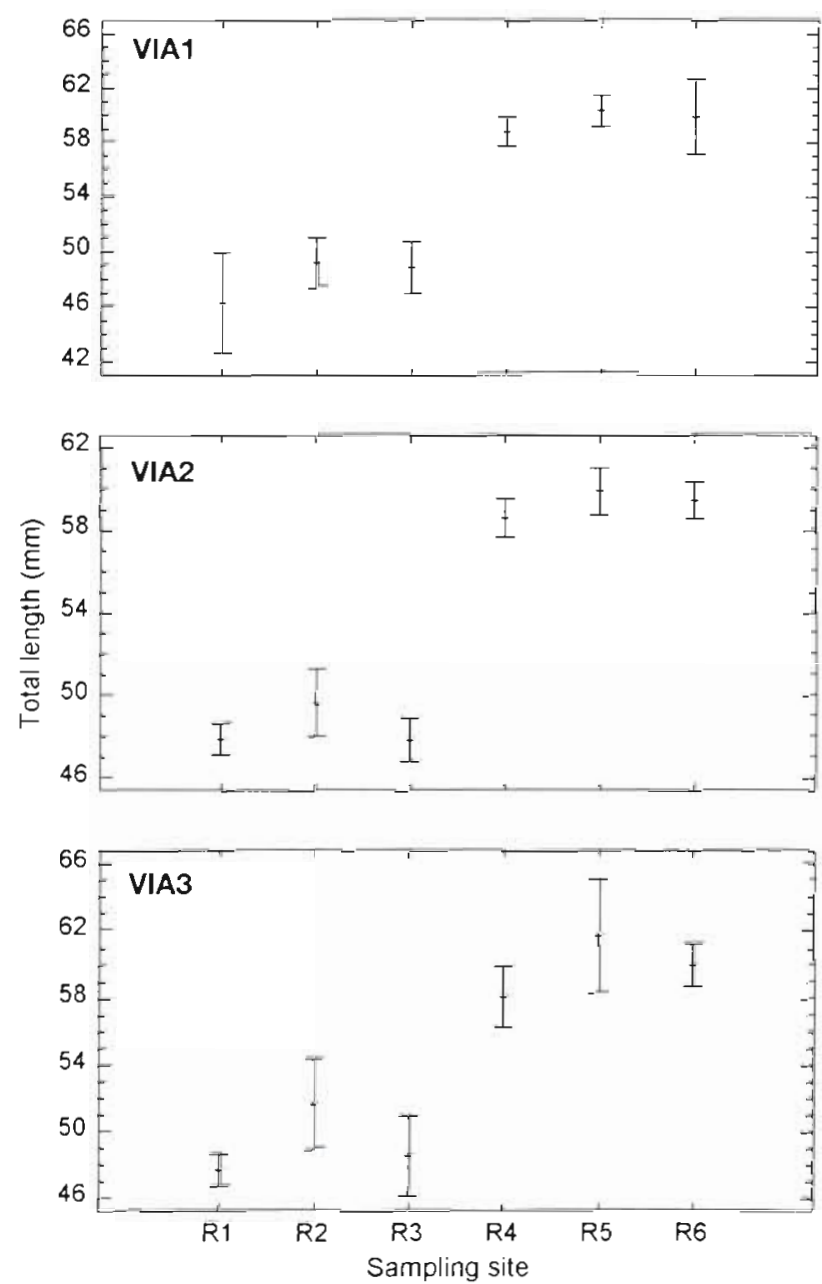

Fig. 4. Anguilla rostrata. Mean ( $\pm 95^{\circ}$ confidence intervals) total length by pigmentation stage (VIA1, VIA2 and VIA3) of elvers collected from 6 estuaries in Haiti and North America 


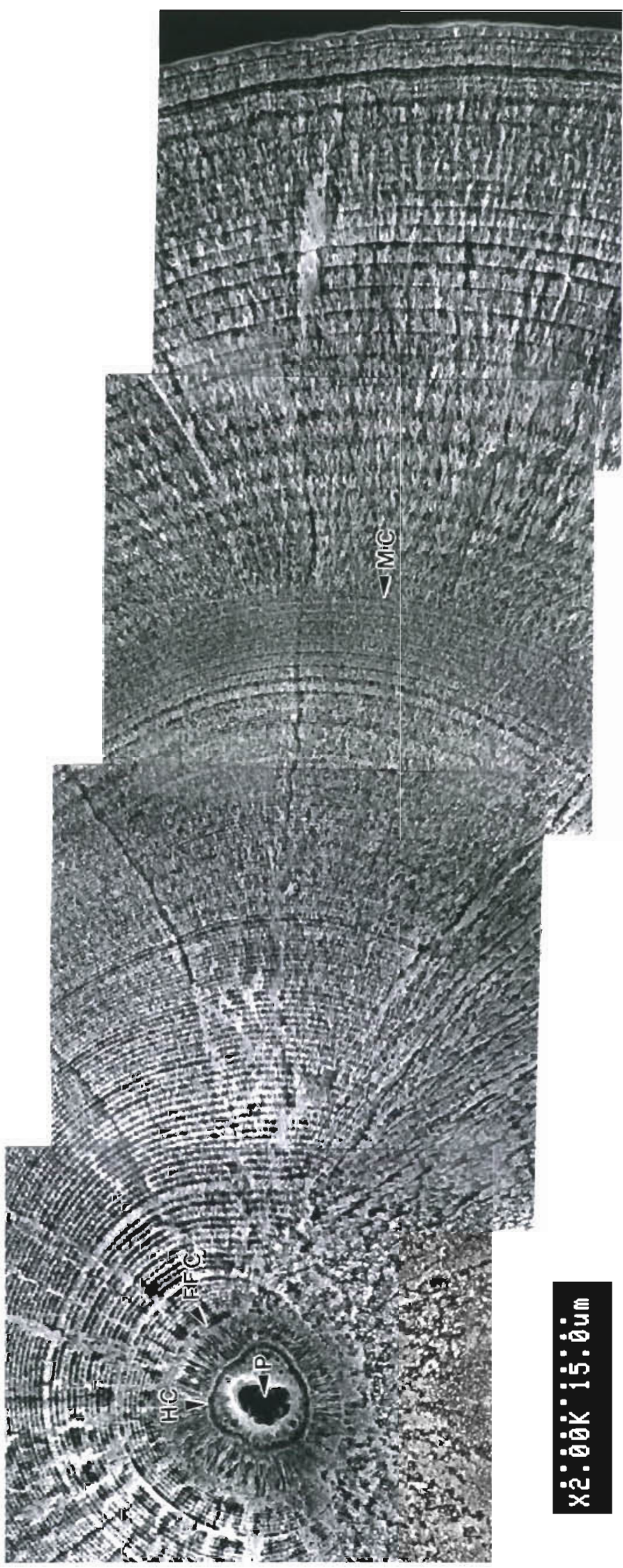

ratios in the otolith has been proposed to correspond to both the time of metamorphosis from leptocephalus to glass eel and the time of migration from oceanic to coastal waters in Anguilla japonica (Otake et al. 1994. Tzeng \& Tsai 1994, Arai et al. 1997).

\section{Geographic trend in otolith growth rate}

The geographic trend in mean growth rate of the elver otoliths at the 6 sampling sites differed in the period before metamorphosis $\left(G_{\mathrm{m}}\right)$ and in the period from metamorphosis to estuarine arrival $\left(G_{t-m}\right)$ (Table 2). $G_{m}$ was larger at the mid-point (R4) of the 6 sampling sites than at the southward and northward sites (R1 and R6) (Table 2). Conversely, the estuarine growth rate $\left(G_{1-\mathrm{m}}\right)$ was larger in the southern group (R1 to R3) than in the northern group (R4 to R6) (Table 2). The geographic trend in $G_{t}$ roughly paralleled that of $G_{t-m}$ because the variance of $G_{t-m}$ was larger than $G_{m}$ (Table 2).

\section{Timing of metamorphosis and estuarine arrival}

The mean ages of the elvers at the 6 sampling sites ranged from 220 to $284 \mathrm{~d}$ at estuarine arrival $\left(T_{1}\right)$ and from 189 to 214 d at metamorphosis $\left(T_{\mathrm{m}}\right)$, with 32 to $80 \mathrm{~d}$ between metamorphosis and estuarine arrival $\left(T_{t-m}\right)$. An analysis of variance (ANOVA) indicated that $T_{\mathrm{t}}, T_{\mathrm{rn}}$ and $T_{1-\mathrm{m}}$ differed significantly among sampling sites (Table 3).

$T_{\mathrm{n}}$ was shortest at the mid-point (R3) of the 6 sampling sites, and increased toward the south (R1 and R2) and north (R4 to R6) (Table 3). On the other hand, $T_{1-m}$ was larger in the northern group ( $R 4$ to $R 6$ ) than the southern group (R1 to R3) (Table 3), consistent with the geographic trend of elver length (Fig. 3). The geographic trend in $T_{1}$ roughly paralleled that of $T_{1-m}$ because the variance of $T_{\mathrm{t}-\mathrm{m}}$ is larger than $T_{\mathrm{m}}$ (Table 3 ). The geographic trends in $T_{\mathrm{m}}$ and $T_{1-\mathrm{m}}$ were inversely related to $G_{\mathrm{m}}$ and $G_{1-\mathrm{m}}$ (Table 2 ).

\section{Relationship between total length and $T_{\mathrm{t}}, T_{\mathrm{m}}$ and $T_{\mathrm{t}-\mathrm{m}}$}

The total length of American eel elvers at estuarine arrival was not significantly correlated with $T_{\mathrm{m}}(\mathrm{r}=$

Fig. 5. Anguilla rostrata. Daily growth increment of an elver $(49.35 \mathrm{~mm}$ ) otolith collected from Haiti (Site R1). FFC: first feeding check; HC: hatching check; MC: metamorphosis check, P: primordium. Scale bar $=15 \mu \mathrm{m}$ 

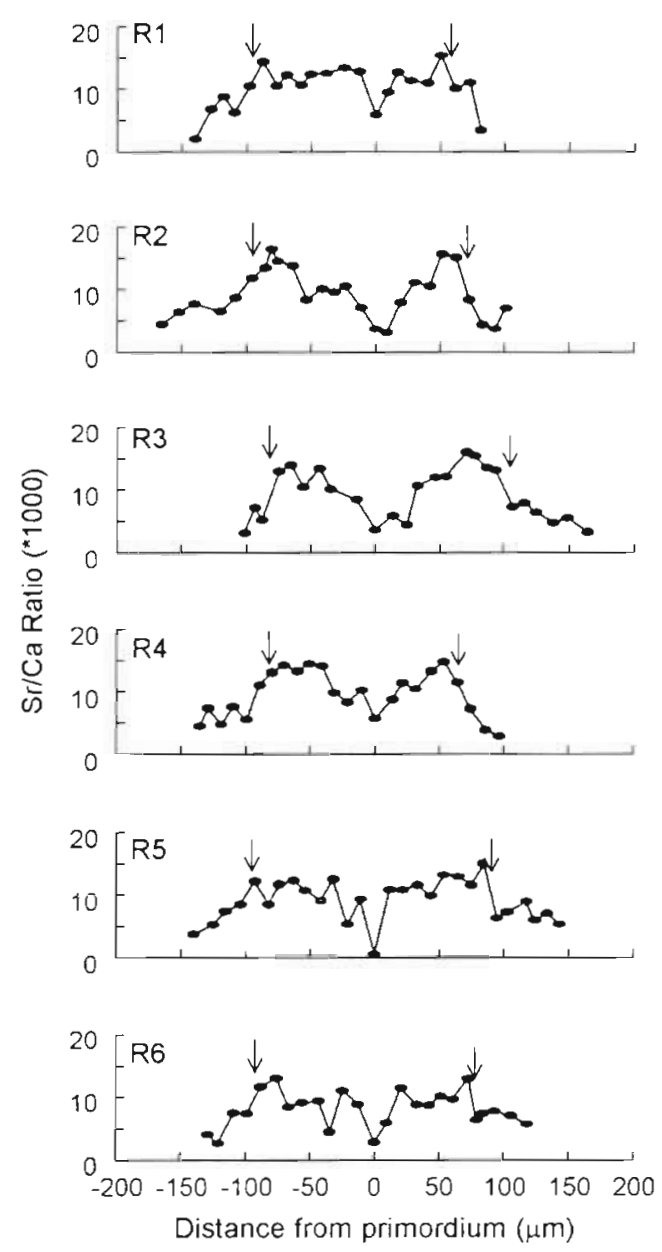

Fig. 6. Anguilla rostrata. Sr/Ca concentration ratios measured along the maximum axis through the primordium of elver otoliths collected from 6 estuaries in Haiti and North America.

Arrows indicate position of the metamorphosis check

$0.00, p>0.05)$, but was significantly positively correlated with $T_{t-m}(r=0.79, p<0.01)$ and also with $T_{t}$ $(\mathrm{r}=0.55, \mathrm{p}<0.01)$ (Fig. 7). Thus, the size of elvers at estuarine arrival increased with the duration from metamorphosis to estuarine arrival, but was independent of the age at metamorphosis

\section{DISCUSSION AND CONCLUSION}

The mean total length of elvers at entry to 6 estuaries on the Atlantic coasts of Haiti, USA and Canada differed significantly between northern and southern groups. Factors which have the potential to influence elver length include pigmentation stage of the elver in the estuary (Tzeng 1985), seasonal decline in length of elvers at entry to the estuary (Strubberg 1913. Matsui 1.952, Jellyman 1979, Tzeng 1985) and annual variability in elver characteristics at entry to the estuary
Table 2. Anguilla rostrata. Homogeneity tests for otolith growth rate (mean $\pm S D, \mu \mathrm{m} \mathrm{d}^{-1}$ ) in elvers in Haiti and North America measured from the primordium to the otolith edge $\left(G_{1}\right)$, to the metamorphosis check $\left(G_{m}\right)$, and between the metamorphosis check and the otolith edge $\left(G_{t-m}\right)$

\begin{tabular}{|c|c|c|c|c|}
\hline & Site & $N$ & Mean $\pm \mathrm{SD}$ & $\begin{array}{c}\text { Homogeneous } \\
\text { groups }\end{array}$ \\
\hline \multirow[t]{7}{*}{$G_{\mathrm{t}}$} & R6 & 17 & $0.528 \pm 0.07$ & A \\
\hline & R5 & 14 & $0.542 \pm 0.06$ & A \\
\hline & $\mathrm{R} 4$ & 18 & $0.586 \pm 0.08$ & $A B$ \\
\hline & R1 & 20 & $0.598 \pm 0.06$ & $A B$ \\
\hline & R2 & 4 & $0.641 \pm 0.05$ & $A B$ \\
\hline & $\mathrm{R} 3$ & 16 & $0.645 \pm 0.08$ & $\mathrm{~B}$ \\
\hline & Total & 89 & $0.584 \pm 0.08$ & \\
\hline \multirow[t]{7}{*}{$G_{m}$} & R6 & 17 & $0.390 \pm 0.04$ & A. \\
\hline & $\mathrm{R} 1$ & 20 & $0.393 \pm 0.05$ & A. \\
\hline & R2 & 4 & $0.411 \pm 0.05$ & $A B$ \\
\hline & R3 & 16 & $0.421 \pm 0.04$ & $A B$ \\
\hline & R5 & 14 & $0.432 \pm 0.04$ & $A B$ \\
\hline & R4 & 18 & $0.460 \pm 0.07$ & $B$ \\
\hline & Total & 89 & $0.418 \pm 0.05$ & \\
\hline \multirow[t]{7}{*}{$G_{t-m}$} & R5 & 14 & $0.813 \pm 0.17$ & $A$ \\
\hline & R6 & 17 & $0.943 \pm 0.21$ & $\mathrm{~A}$ \\
\hline & R4 & 18 & $0.975 \pm 0.23$ & A \\
\hline & R1 & 20 & $1.981 \pm 0.33$ & $B$ \\
\hline & R3 & 16 & $2.019 \pm 0.71$ & B \\
\hline & $\mathrm{R} 2$ & 4 & $2.106 \pm 0.14$ & B \\
\hline & Total & 89 & $1.408 \pm 0.66$ & \\
\hline
\end{tabular}

Table 3. Anguilla rostrata. Homogeneity test for daily age (mean \pm SD) of elvers from estuaries in Haiti and North America $\left(T_{1}\right)$, for daily age at metamorphosis $\left(T_{m}\right)$, and for the time between metamorphosis and arrival at the estuary $\left(T_{--m}\right)$

\begin{tabular}{|c|c|c|c|c|}
\hline & Site & $N$ & Mean $\pm \mathrm{SD}$ & $\begin{array}{c}\text { Homogeneous } \\
\text { groups }\end{array}$ \\
\hline \multirow[t]{7}{*}{$T_{1}$} & R3 & 21 & $220.4 \pm 33.22$ & A \\
\hline & R1 & 25 & $241.6 \pm 18.51$ & B \\
\hline & R2 & 4 & $247.8 \pm 16.24$ & $\mathrm{BC}$ \\
\hline & R4 & 26 & $251.8+16.62$ & $\mathrm{BCD}$ \\
\hline & R5 & 17 & $272.3 \pm 15.72$ & CDE \\
\hline & R6 & 32 & $283.5 \pm 18.18$ & $E$ \\
\hline & Total & 125 & $255.3 \pm 30.24$ & \\
\hline \multirow[t]{7}{*}{$T_{\mathrm{m}}$} & R3 & 21 & $188.8 \pm 29.14$ & A \\
\hline & R4 & 26 & $189.5 \pm 19.63$ & A \\
\hline & R5 & 17 & $192.7 \pm 20.33$ & $A B$ \\
\hline & $\mathrm{R} 1$ & 25 & $209.3 \pm 20.20$ & $A B$ \\
\hline & R6 & 32 & $211.4 \pm 20.75$ & B \\
\hline & $\mathrm{R} 2$ & 4 & $214.0 \pm 14.35$ & B \\
\hline & Total & 125 & $200.2 \pm 23.84$ & \\
\hline \multirow[t]{7}{*}{$T_{t-m}$} & R3 & 21 & $31.7 \pm 5.84$ & A \\
\hline & R 1 & 25 & $32.7 \pm 4.44$ & A \\
\hline & $\mathrm{R} 2$ & 4 & $33.8 \pm 3.86$ & A \\
\hline & $\mathrm{R} 4$ & 26 & $62.2 \pm 11.13$ & B \\
\hline & R6 & 32 & $72.2 \pm 12.17$ & $\mathrm{C}$ \\
\hline & R5 & 17 & $79.6 \pm 14.07$ & C \\
\hline & Total & 125 & $55.1 \pm 21.85$ & \\
\hline
\end{tabular}



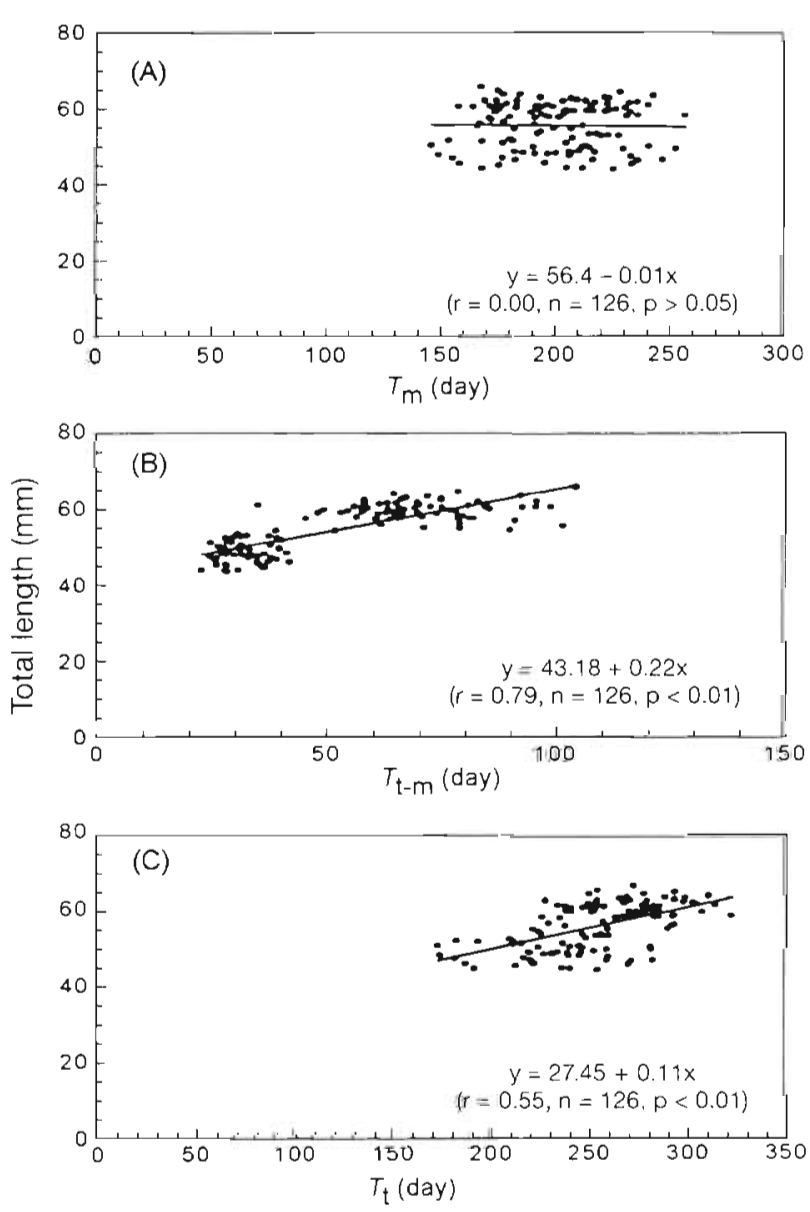

Fig. 7. Anguilla rostrata. Relationships between total length of elvers and (A) age of leptocephali at metamorphosis $\left(T_{m}\right)$, (B) time between metamorphosis and arrival at the estuaries $\left(T_{1-\mathrm{m}}\right)$ and $(\mathrm{C})$ age at estuarine arrival $\left(T_{t}\right)$

(Haro \& Krueger 1988). Pigmentation stage was found to have no effect on the elver length at estuarine arrival. Annual variability was negligible because the elvers from all estuaries were collected during 1995. Also, the elvers collected from Florida in 1995 and 1997 had similar length distributions. Within an estuary, elver length tends to decline through the run (Tzeng 1985). Run timing is earlier in the southern than in the northern portions of the range and elver length increases from south to north (Vladykov 1966. Haro \& Krueger 1988). The observed size difference of $12 \mathrm{~mm}$ between the mean lengths of elvers from Haiti and Canada was larger than the seasonal decline, which is usually less than 6\% in American eel (Haro \& Krueger 1988). The geographic difference in elver length of American eel was not due to differences in sampling date.

Haro \& Krueger (1988) proposed that the geographic trend in elver length may be due to the variation in the timing of metamorphosis of leptocephali to the glass eel stage. However, we found that the correlation between the age at metamorphosis and the length of elvers at estuarine entry was not significant, although the correlation between elver length and the time between metamorphosis and entry to estuaries was significant. This indicated that the geographic difference in elver length along the east coast of North America was correlated with the difference in the duration of the glass eel stage in coastal waters. In coastal waters, the glass eel phase in the northern part of the range lasted approximately 62 to $80 \mathrm{~d}$, which is 2 to 3 times longer than in the southern part of the range (32 to $34 \mathrm{~d}$ ). Thus, higher elver length at northern sites in comparison to southern sites may be due to the longer duration of the glass eel phase in coastal waters. The early life history, described in the following, of the elver contributes to the further understanding of this relationship.

The early life history of the American eel Anguilla rostrata is similar to that of the Japanese eel Anguilla japonica (Tsukamoto 1990, 1992, Tsukamoto \& Umezawa 1990, 1994), with 2 distinct stages: the leptocephalus in the open ocean and the glass eel and elver in coastal waters. American eels spawn in the southwestern Sargasso Sea, after which the leptocephalus drifts with the Florida Current and Gulf Stream, then metamorphoses into a glass eel as it approaches the continental shelf and becomes an elver at entry to the estuary. The geographic trend in the mean daily ages of the leptocephalus $\left(T_{\mathrm{m}}\right)$ and the time from metamorphosis to arrival at the estuary $\left(T_{t-m}\right)$ differed among the 6 estuaries sampled. $T_{\mathrm{m}}$ was smallest at the midpoint of the 6 sampling sites (North Carolina) and increased towards the southern sites (Haiti and Florida) and northern sites (New Brunswick and Nova Scotia). On the other hand, $T_{1-m}$ was smaller in the south (Haiti to North Carolina) than in the north (Rhode Island to Nova Scotia). This suggests that the migration and dispersal patterns differ between the leptocephalus and glass eel stages. In addition, there was an inverse geographic trend between growth rate and leptocephalus age at metamorphosis. This indicates that faster-growing and earlier-metamorphosing leptocephali entered the middle of the sampling range, while slower-growing, delayed-metamorphosis leptocephali dispersed southward and northward. This result is consistent with leptocephali entering the Gulf Stream system directly from the Sargasso Sea, as postulated by Kleckner \& McCleave (1982), rather than by a more southern route through the Bahamas.

However, when the eel metamorphoses from leptocephalus to glass eel and enters coastal waters, geographic trends in age $\left(T_{1-\mathrm{m}}\right)$ and growth rate $\left(G_{1-\mathrm{m}}\right)$ differed completely from that of the leptocephalus in the open ocean. $T_{1-m}$ was smaller in the southern part 
of the sampling range (Haiti to North Carolina) than in the northern part (Rhode Island to Nova Scotia), but $G_{t-m}$ was the opposite, being smaller in the north than in the south. Thus, glass eels grew faster, but stayed in coastal waters a shorter time, in the south than in the north. The duration of the glass eel phase in coastal waters may be regulated by coastal oceanographic conditions. The coastal waters of the southem sampling sites (Haiti to North Carolina) are influenced by the warm Gulf Stream, but the northern waters (Rhode Island to Nova Scotia) are influenced by the cold Labrador Current (Lalli \& Parsons 1993). Higher temperatures in the south will accelerate the development of the glass eel, producing faster glass eel growth, more rapid elver development and earlier immigration to the estuary in the south than in the north. Although growth of the elver in the glass eel phase was faster in the south, their duration in coastal waters was shorter, which may lead to a smaller total length of elvers at entry to the estuary in the south than in the north.

In conclusion, the American eel Anguilla rostrata elvers are smaller in the southern than in the northern estuaries of the Atlantic coast of North America because the duration of the glass eel phase in the coastal waters is shorter in the southern than in the northern part of their range and not because of differences in the timing of metamorphosis from leptocephalus to glass eel.

Acknowledgements. This study was financially supported by the National Science Council, Republic of China (NSC 852311B002032, a research project to W.N.T.). The authors are grateful to Dr $G$. Williamson for arranging the sampling, to Dr W. H. Krueger, Mr B. M. Jessop and Mr A. T Peng for providing the fish specimens from the United States, Canada and Haiti, to Dr C. H. Chen for electron probe microanalysis, and to Mr B. M. Jessop and Dr S. E. Campana for reviewing the manuscript.

\section{LITERATURE CITED}

Arai T, Otake T, Tsukamoto K (1997) Drastic changes in otolith microstructure and microchemistry accompanying the onset of metamorphosis in the Japanese eel Anguilla japonica. Mar Ecol Prog Ser 161:17-22

Avise JC, Helfman GS, Saunders NC, Hales LS (1986) Mitochondrial DNA differentiation in North Atlantic eels: population genetic consequences of an unusual life history pattern. Proc Natl Acad Sci USA 83:4350-4354

Bertin L (1956) Eels - a biological study. Cleaver-Hume Press, London

Campana SE (1.984) Microstructural growth patterns in the otoliths of larval and juvenile starry flounder, Platichthys stellatus. Can J Zool 62:1507-1512

Campana SE, Neilson JD (1985) Microstructure of fish otoliths. Can J Fish Aquat Sci 42:1014-1032

Castonguay M, McCleave JD (1987) Vertical distributions, diel and ontogenetic vertical migrations and net avoidance of leptocephali of Anguilla and other common spe- cies in the Sargasso Sea. J Plankton Res 9:195-214

Chen $\mathrm{CH}$, Tung TC (1984) On-line data reduction for electron microprobe analysis. Acta Geol Taiwan 22:196-200

Cheng PW, Tzeng WN (1996) Timing of metamorphosis and estuanes arrival across the dispersal range of the Japanese eel Anguilla japonica. Mar Ecol Prog Ser 131:87-96

Goldstein JT, Newbury DE, Echlin P, Joy DC. Fiori C, Lifshin E (1984) Scanning electron microscopy and $x$-ray microanalysis. Plenum Press, New York

Haro AJ, Krueger WH (1988) Pigmentation, size, and migration of elvers (Anguilla rostrata (Lesueur)) in a coastal Rhode Island stream. Can J Zool 66:2528-2533

Jellyman DJ (1979) Upstream migration of glass-eels (Anguilla spp.) in the Waikato River. Ibid 13(1):13-22

Kleckner RC, McCleave JD (1982) Entry of migrating American eel leptocephali into the Gulf Stream system. Helgoländer Meeresunters 35:329-339

Kleckner RC, McCleave JD (1985) Spatial and temporal distribution on American eel larvae in relation to North Atlantic Ocean current systems. Dana 4:67-92

Kleckner RC, McCleave JD (1988) The northern limit of spawning by Atlantic eels (Anguilla spp.) in the Sargasso Sea in relation to thermal fronts and surface water masses. J Mar Res 46:647-667

Kleckner RC, McCleave JD, Wippelhauser GS (1983) Spawning of Amencan eel, Anguilla rostrata, relative to thermal fronts in the Sargasso Sea. Environ Biol 9:289-293

Lalli CM, Parsons TR (1993) Biological oceanography-an introduction. Pergamon Press, Oxford

Martin MH (1995) Validation of daily growth increments in otoliths of Anguilla rostrata (Lesueur) elvers. Can J Zool 73:208-211

Matsui I (1952) Studies on the morphology, ecology and pondculture of the Japanese eel (Anguilla japonica Temminck \& Schlegel). J Shimonoseki Coll Fish 2:1-245

Miller MJ, McCleave JD (1.994) Species assemblages of leptocephali in the Subtropical Convergence Zone of the Sargasso Sea. J Mar Res 52:743-772

Otake T, Ishii T, Nakahara M, Nakamura R (1994) Drastic changes in otolith strontium/calcium ratios in leptocephali and glass eels of Japanese eel Anguilla japonica. Mar Ecol Prog Ser 112:189-1.93

Pannella G (1971) Fish otoliths: daily growth layers and periodical patterns. Science 173:1124-1127

Schmidt J (1909) Remark on the metamorphosis and distribution of the eel (Anguilla vulgaris TURT.). Meddr Komm Havunders Ser Fisk 3(3):1-17

Schmidt J (1925) The breeding places of the eel. Rep Smithson Inst 1924:279-316

Schoth M, Tesch FW (1982) Spatial distribution of 0-group eel larvae (Anguilla sp.) in the Sargasso Sea. Helgoländer Meeresunters 35:309-320

Smith DG (1968) The occurrence of larvae of the Amencan eel, Anguilla rostrata, in the Straits of Florida and nearby areas. Bull Mar Sci 18:280-293

Sokal RR, Rohlf FJ (1969) Biometry. WH Freeman, San Francisco

Strubberg AC (1913) The metamorphosis of elvers as influenced by outward conditions. Medd Komm Dan Fisk Havunders $4: 1-11$

Tesch FW (1977) The eel-biology and management of Anguilla eel. Chapman and Hall Press, London

Tsukamoto K (1990) Recruitment mechanism of the eel Anguilla japonica, to the Japanese coast. J Fish Biol 36 $359-371$

Tsukamoto K (1992) Discovery of spawning area for Japanese eel. Nature 356:789-791 
Tsukamoto K, Umezawa A (1990) Early life history and oceanic migration of the eel Anguilla japonica. La Mer 28: $188-198$

Tsukamoto K, Umezawa A (1994) Metamorphosis: a key factor of larval migration determining geographic distribution and speciation of eels. In: Proc 4th Indo-Pacific Fish Conf, Bangkok, Thailand, 28 Nov-4 Dec 1993. Faculty of Fisheries, Kasetart University, Bangkok, p 231-248

Tzeng WN (1985) Immigration timing and activity rhythms of the eel, Anguilla japonica, elvers in the estuary of northern Taiwan with emphasis of environmental influences Bull Jpn Soc Fish Oceanogr 47/48:11-28

Tzeng WN (1990) Relationship between growth rate and age at recruitment of Anguilla japonica elvers in the Taiwan estuary as inferred from otolith growth increment. Mar Biol 107:75-81

Tzeng WN (1996) Effects of salinity and ontogenetic movement on strontium:calcium ratio in otolith of the Japanese eel, Anguilla japonica Temminck \& Schlegel. J Exp Mar Biol Ecol 199:111-122

Editorial responsibility: Otto Kinne (Editor), Oldendorf/Luhe, Germany
Tzeng WN, Tsai YC (1994) Changes in otolith microchemistry of the Japanese eel, Anguilla japonica, during its migration from the ocean to the rivers of Taiwan. J Fish Biol 45:671-683

Usui A (1991) Eel culture. Fishing News Books. Blackwell Scientific Publications Inc, Oxford

Vladykov VD (1966) Remarks on the American eel (Anguilla rostrata Lesueur). Sizes of elvers entering streams; the relative abundance of adult males and females; and the present economic importance of eels in North America. Verh Int Verein Theor Angew Limnol 16:1007-1017

Volk EC, Wissmar RC, Simenstad CA, Eggers DM (1984) Relationship between otolith microstructure and the growth of juvenile chum salmon (Oncorhynchus keta) under different prey rations. Can J Fish Aquat Sci 41:126-133

Yamamoto K, Yamauchi K (1974) Sexual maturation of Japanese eel and production of eel larvae in the aquarium. Nature 251:220-222

Yamauchi K, Nakamura M, Takahashi H, Takano K (1976) Cultivation of larvae of Japanese eel. Nature 263:412

Submitted: September 15, 1997; Accepted: January 22, 1998 Proofs received from author(s): June 15, 1998 